\title{
PENDEKATAN FILOSOFIS PSIKOLOGI PENDIDIKAN SEBAGAI UPAYA PENCAPAIAN TUJUAN PEMBELAJARAN KESENIAN SEKURA DI SD TUNAS MEKAR INDONESIA, BANDAR LAMPUNG
}

\author{
DIAN ANGGRAINI, S.Sn. \\ Email: danggarini75@gmail.com \\ INSTITUTE SENI BUDAYA INDONESIA BANDUNG
}

\begin{abstract}
Sekura art is one of the arts that undergo development based on the occurrence of switching function. Based on the implementation there are two types sekura division, namely Sekura Kecah or Clean and Sekura Sekura Sekura Kamak or Kotor. Currently Sekura art has become a folk art tends to be familiar with the Lampung people because always present in any custom events, the celebration of Eid, and even be used as teaching materials in some of Elementary School (SD) Bandar Lampung. The learning of sekura art at SD Tunas Mekar Indonesia, Bandar Lampung was used as the focus of the research. The expected learning objectives are the development of student character that is adjusted to his age. In this case the embedded character expected of students who love the country, respect, honor, love, and care for others and the surrounding environment. In addition it is expected also embedded creative and innovative soul that is accompanied by a sense of responsibility is also hard work. It is pursued through philosophical approach of educational psychology. The results of this study is to instill the character of students in elementary Tunas Mekar Indonesia, Bandar Lampung, which is expected to be realized through arts learning tends to be effective sekura do with a philosophical approach to educational psychology.
\end{abstract}

Keywords: Philosophical Approach, Educational Psychology, Learning Objectives, Sekura Arts Lampung.

\section{A. PEndahuluan}

Karya seni adalah ekspresi atau perwujudan sesuatu yang dibentuk tidak melalui berbagai perbedaan tetapi melalui elemen yang harmonis sebagai kesatuan keseluruhan untuk dinikmati secara estetis (Jacqueline Smith terjemahan Ben Suharto, 1995:30). Seni merupakan media pengantar dan wahana komunikasi yang baik dan pada hakikatnya merupakan bentuk ekspresi jiwa manusia yang 
dituangkan lewat imajinasi secara bebas dan sadar dalam bentuk sebuah karya dengan tidak mengurangi norma dan etika yang ada.

Lampung merupakan salah satu provinsi yang di kenal sebagai daerah transmigrasi, sehingga daerah ini memiliki sebutan Sai Bumi Rua Jurai: yang artinya satu bumi dari dua asal masyarakat, masyarakat pendatang dan masyarakat asli. Sudah hampir satu abad lamanya masyarakat pendatang dan masyarakat asli daerah Lampung hidup berdampingan. Masyarakat asli adalah masyarakat yang telah ada sejak dahulu dan memiliki ciri khas adat istiadat yang telah berkembang berabad-abad lalu. Seperti halnya daerah-daerah lain di Indonesia, masyarakat Lampung asli juga memiliki berbagai kegiatan adat budaya.

Kegiatan-kegiatan adat budaya ini selalu dikaitkan dengan peristiwa penting dalam kehidupan seseorang atau masyarakat. Berbagai kegiatan adat yang ada tidak terlepas dari bentuk kegiatan seni yang merupakan penanganan hasrat penciptaan kreatif di dalam masyarakat. Sebagaimana telah dikemukakan oleh Koentjaraningrat bahwa kesenian merupakan salah satu dari unsur kebudayaan, yang merupakan salah satu perwujudan 'jati diri' bangsa Indonesia serta mempunyai ciri khas sebagai gambaran kehidupan manusia dari berbagai etnik. Ada banyak keanekaragaman kesenian etnik yang terdapat di Indonesia, salah satunya adalah kesenian Topeng di Lampung.

Topeng merupakan salah satu alat yang digunakan untuk menutup wajah, dikenal pada beberapa suku bangsa di Indonesia. Bentuk dan fungsinya bermacam-macam. Topeng merupakan benda hasil budaya manusia yang mungkin sudah setua kebudayaan manusia itu sendiri. Secara umum dapat dikatakan bahwa topeng merupakan salah sartu wujud ekspresi simbol yang dibuat manusia untuk maksud tertentu. Topeng juga dapat diartikan sebagai suatu tiruan wajah yang dibentuk atas bahan dasar yang tipis atau ditipiskan, dengan memperhitungkan kelayakannnya untuk dikenakan di wajah manusia sehingga wajah yang mengenakannya tertutup sebagian atau menyeluruh. Terdapat beberapa alasan manusia membuat topeng, salah satunya adalah untuk menutupi identitas diri. 'Pribadi' yang melambangkan dengan topeng itu beraneka macam pula, tidak hanya terbatas pada sesama manusia, melainkan juga tokoh-tokoh gaib, dari yang bercitra kemanusiaan dan bertataran kedewataan sampai yang 
bercitra kebinatangan dan bertataran lebih rendah dari pada manusia. Fungsi dalam sistem kebudayaan yang dipenuhi oleh topeng dapat dibedakan atas fungsi keagamaan dan fungsi kesenian.

Fungsi topeng yang pertama merupakan sarana ekspresi simbolis untuk mewujudkan konsepsi-konsepsi keagamaan, khususnya yang berkenaan dengan kekuatan-kekuatan gaib tertentu. Fungsi yang kedua, topeng merupakan ekspresi simbolis untuk menyalurkan tanggapan-tanggapan kesan atas alam beserta sifatsifatnya, maupun atas konsep-konsep budaya tertentu melalui bentukan-bentukan visual yang terencana. (Jurnal masyarakat seni pertunjukan Indonesia, 1993:3)

Dalam hubungan ini dapat dikemukakan hipotesis bahwa dalam kebudayaan suku-suku bangsa di Indonesia topeng pada awal mempunyai fungsi keagamaan. Kemudian dalam perkembangannya beralih dan merangkap menjadi fungsi dari kesenian. Topeng juga dapat digolongkan berdasarkan ukuran dan gaya perwujudan visualnya. Berdasarkan ukurannya, topeng dapat digolongkan atas topeng besar dan topeng kecil. Topeng besar adalah topeng yang berukuran di atas ukuran normal wajah manusia, sedangkan topeng kecil adalah topeng yang kurang lebih seukuran dengan wajah manusia. Contoh dari topeng kecil ialah topeng-topeng yang biasannya digunakan untuk menari (topeng pajengan di Bali, topeng untuk tari topeng di Cirebon dan Jawa, sekura/tupping untuk tari topeng di Lampung). Topeng juga digolongkan berdasarkan gaya perwujudan visualnya. Secara garis besar dapat dipisahkan antara yang bergaya natural, yaitu dalam pemberian bentuk maupun proporsi antara bagian-bagiannya terdapat kesejajaran dengan wujud-wujud yang dikenal di alam nyata, dan yang bergaya grotesk, yaitu yang pemberian bentuk maupun proporsi internalnya tidak mengacu secara setia kepada alam nyata. (Jurnal masyarakat seni pertunjukan Indonesia, 1993:3)

Berdasarkan penjelasan singkat tersebut, terdapat salah satu topeng yang menarik di Lampung. Lampung merupakan salah satu wilayah yang juga menggunakan pemakaian topeng. Topeng di masyarakat Lampung digunakan sebagai penutup identitas atau penyamaran dari para penjajah yang saat itu menjajah wilayah Lampung. Masyarakat Lampung menyebut topeng dengan sebutan 'sekura' (wilayah Lampung Barat) atau 'tupping' (wilayah Lampung Selatan). Tidak ada perbedaan yang signifikan dari kedua daerah tersebuat atas 
penggunaan topeng, namun penyebutannya saja yang berbeda. Di Lampung pada awalnya topeng digunakan sebagai sarana untuk menyembunyikan identitas diri, bersembunyi dari para penjajah.

Berdasarkan permasalahan diatas, maka peneliti mengadakan penelitian dengan judul "Pendekatan Filosofis Psikologi Pendidikan Sebagai Upaya Pencapaian Tujuan Pembelajaran Kesenian Sekura di SD Tunas Mekar Indonesia Bandar Lampung".

\section{B. KAJIAN TEORI}

Diketahui bahwa setiap kesenian memiliki nilai dan makna masingmasing. Adapun nilai yang terdapat dalam kesenian sekura ialah nilai keagamaan, sosial, dan pendidikan. Makna yang terdapat di dalamnya pun berkembang sesuai dengan perkembangan masyarakat sebagai publik yang memberikan pemaknaan terhadap kesenian tersebut.

Diketahui pula bahwa perkembangan manusia dalam masyarakat terus mengalami perkembangan. Perkembangan tersebut diperoleh dari proses belajar. Pengertian belajar dikatakan oleh Slameto dalam Hamdani bahwa belajar adalah proses usaha yang dilakukan seseorang untuk memperoleh perubahan tingkah laku yang baru secara keseluruhan, sebagai hasil pengalamannya sendiri dalam interaksi dengan lingkungannya. (Hamdani, 2011:20) Dengan kata lain manusia yang terus berinteraksi dengan lingkungannya secara tak langsung juga belajar untuk menyesuaikan diri dengan lingkungannya. Sehingga diperoleh tingkah laku yang lebih baik dari sebelumnya berdasarkan hasil proses belajar tersebut.

Dimyati dalam Hamdani menambahkan pendapat tentang belajar bahwa belajar merupakan tindakan dan perilaku siswa yang kompleks. (Jurnal masyarakat seni pertunjukan Indonesia, 1993:71) Dengan demikian poses belajar yang dilakukan siswa di sekolah meliputi berbagai tindakan yang dilakukan siswa dalam proses pembelajaran yang cenderung bersifat dinamis.

Terkait dengan perkembangan masyarakat Lampung saat ini yang turut berkembang sesuai dengan era globalisasi, dibutuhkan pondasi yang kuat, yaitu nilai-nilai kearifan lokal. Adapun nilai-nilai kearifan lokal perlu digalakkan kembali untuk ditanamkan pada generasi penerus yang diharapkan kelak 
melahirkan generasi berikutnya yang berdaya saing di era global dengan tidak melupakan nilai-nilai kearifan lokalnya sebagai identitas bangsa Indonesia.

Terkait hal tersebut dibutuhkan berbagai upaya, dimulai dari lingkungan keluarga sebagai lingkungan sosial terkecil, lingkungan sekolah sebagai lingkungan masyarakat ke-dua, dan lingkungan masyarakat luas pada lingkup selanjutnya yang lebih luas.

Upaya penanaman nilai-nilai kearifan lokal dalam lingkup keluarga dapat disesuaikan dengan cara didik dalam keluarga masing-masing. Selanjutnya pada upaya yang dilakukan di lingkungan sekolah dibutuhkan metode pembelajaran tertentu yang efektif dan efisien dengan turut mempertimbangkan karakter peserta didik.

Terkait pemilihan metode pembelajaran tersebut, dapat dilakukan pendekatan filosofis dalam psikologi pendidikan terlebih dahulu. Hal ini diperlukan karena pada setiap materi pembelajaran diharapkan muncul karakter peserta didik yang bertanggung jawab, kerja keras, cinta tanah air, peduli, saling menghargai, menghormati, dan menyayangi antar sesama.

Guna memunculkan karakter tersebut dapat diupayakan melalui pendekatan filosofis dalam psikologi pendidikan. Hal ini dikarenakan dalam ranah pendekatan filosofis terdapat ontologi, epistemologi, dan aksiologi sebagai struktur pembentuk ilmu pengetahuan. Ilmu pengetahuan tersebut nantinya dapat mempengaruhi upaya pengoptimalan pekembangan siswa kelas 4 SD Tunas Mekar Indonesia, Bandar Lampung yang disesuaikan dengan perkembangan anak pada rentang usia 6-12 tahun menurut Erikson.

Pendekatan filosofis tersebut merupakan wujud dari salah satu penerapan psikologi pendidikan yang nantinya dapat berkontribusi dalam mewujudkan pembelajaran yang efektif dan efisien.

Dijelaskan definisi psikologi pendidikan menurut Sultan Muhammad (2008) dalam Sudarwan Danim dan H. Khairil (2010: 6) adalah aplikasi dari temuan psikologis di bidang pendidikan. Dengan demikian, psikologi pendidikan adalah studi sistematis tentang perkembangan individu dalam lingkungan pendidikan. Psikologi pendidikan merupakan disiplin ilmu terapan yang menggabungkan dua bidang berbeda, yaitu pendidikan dan psikologi. Psikologi 
pendidikan adalah studi ilmiah untuk memahami, memprediksi, dan mengarahkan perilaku siswa bagi usaha pencapaian tujuan pendidikan dan pembelajaran.

Adapun kontribusi psikologi pendidikan masih menurut Sultan Muhammad (2008) dalam Sudarwan Danim dan H. Khairil (2010: 60) antara lain: (1) memahami karakteristik perkembangan siswa; (2) memahami sifat kelas atau ruang belajar; (3) memahami perbedaan individu; (4) memahami metode pengajaran yang efektif; (5) pengetahuan tentang kesehatan mental; (6) konstruksi kurikulum; (7) pengukuran hasil atau dampak pembelajaran; dan (8) pedoman layanan pendidikan anak-anak luar biasa.

\section{METODE PENELITIAN}

Metode dalam penelitian ini menggunakan pendekatan filosofis dalam psikologi pendidikan. Hal ini dikarenakan dalam ranah pendekatan filosofis terdapat ontologi, epistemologi, dan aksiologi sebagai struktur pembentuk ilmu pengetahuan. Ilmu pengetahuan tersebut nantinya dapat mempengaruhi upaya pengoptimalan pekembangan siswa kelas 4 SD Tunas Mekar Indonesia, Bandar Lampung yang disesuaikan dengan perkembangan anak pada rentang usia 6-12 tahun menurut Erikson.

Pendekatan filosofis tersebut merupakan wujud dari salah satu penerapan psikologi pendidikan yang nantinya dapat berkontribusi dalam mewujudkan pembelajaran yang efektif dan efisien.

Berdasarkan pendekatan filosofis tersebut, pada penelitian yang dilakukan di SD Tunas Mekar Indonesia, Bandar Lampung, fokus pada siswa kelas 4, dikembangkan menjadi enam tema sebagai berikut: (1) dasar ontologis, yaitu guru harus mengetahui dan memahami fokus dari kesenian sekura sebagai substansi materi pembelajaran seni budaya; (2) dasar semantik, yaitu guru harus mampu menyampaikan hal-hal terkait kesenian sekura sebagai substansi materi pembelajaran seni budaya; (3) dasar epistemologi, yaitu guru harus mampu mentransformasikan, mengembangkan, dan mencari startegi-strategi baru dalam mengupayakan pembelajaran yang efektif dan efisien dalam materi kesenian sekura; (4) dasar aksiologis, yaitu guru harus mampu menjelaskan dan mensugesti siswa akan pentingnya mempelajari kesenian sekura; (5) dasar metodologis, yaitu 
guru harus memahami prosedur, dan metode mempelajari kesenian sekura, serta mengembangkan pengetahuan yang relevan dengan substansi tersebut; dan (6) dasar etika, yaitu guru harus mampu memahami dan memaknai pertimbangan moral dan nilai yang dihasilkan dari proses pembelajaran, disesuaikan pula dengan karakter yang diharapkan dalam tujuan pembelajaran.

Terkait pendekatan filosofis dalam kerangka pembelajaran menurut paparan Sudarwan Danim dan H. Khairil menganut empat aliran, sebagai berikut: (1) essensialisme, berupa kegiatan pembelajaran yang menekankan pada esensi pewarisan budaya serta transformasi pengetahuan dan keterampilan pada peserta didik agar dapat menjadi anggota masyarakat yang berguna; (2) eksistensialisme, berupa kegiatan pembelajaran yang memposisikan siswa sebagai sumber pengetahuan kehidupan dan maknanya. Siswa tidak hanya dituntut untuk mau dan mampu belajar, tetapi juga memahami dirinya sendiri; (3) progresivisme, berupa kegiatan pembelajaran yang menakankan pada layanan atas perbedaan individual siswa, pembelajaran berpusat pada peserta didik, variasi pengalaman dan proses dalam pembelajaran, dan sebagainya; dan (4) rekonstruktivisme, berupa kegiatan pembelajaran yang mengelaborasi aliran progresivisme sekaligus menuntut siswa mampu berpikir kritis, memecahkan masalah, dan sebagainya.

Pada penelitian ini pendekatan filosofis dalam kerangka pembelajaran cenderung mengacu pada aliran essensialisme, yaitu berupa kegiatan pembelajaran yang menekankan pada esensi pewarisan budaya serta transformasi pengetahuan dan keterampilan pada peserta didik agar dapat menjadi anggota masyarakat yang berguna. Pada penenlitian tersebut diterapkan kesenian sekura sebagai substansi materi pembelajaran.

\section{PEMBAHASAN}

Pada ranah pendekatan filosofis terdapat ontologi, epistemologi, dan aksiologi sebagai struktur pembentuk ilmu pengetahuan. Ontologi berkaitan dengan apa ilmu itu?, epistemologi berhubungan dengan bagaimana asal usul ilmu itu?, sedangkan aksiologi terkait dengan apa manfaat ilmu itu bagi masyarakat?.

Pada penelitian ini kesenian sekura berposisi sebagai ilmu tersebut sekaligus substansi materi dalam mata pelajaran di SD Tunas Mekar Indonesia. 
Terkait ontologi, epistemologi, dan aksiologi kesenian sekura dijelaskan pada paragraf selanjutnya. Selain ketiganya juga akan dijelaskan pengalaman etik (sudut pandang peneliti) sebagai partisipan observer (peneliti terlibat langsung dalam penelitian) yang disesuaikan dengan pengalaman emik (pandangan masyarakat yang dikaji).

Segala hal yang menunjukkan tentang kesenian sekura, asal usul kesenian sekura, dan manfaat kesenian tersebut tak lepas dari pemaknaan masyarakat sebagai publik terhadap kesenian itu.

Diketahui bahwa makna dalam sebuah kesenian merupakan hal yang telah lama ada, mungkin usianya sama dengan keseniannya. Makna-makna tersebut dihadirkan dalam bentuk yang memiliki tingkat kesulitan yang berbeda-beda dalam penafsirannya. Tingkatan tersebut berupa seberapa mudahnya makna dalam sebuah kesenian dapat diinterpretasi secara langsung, melalui penelaahan baru dapat ditafsirkan, atau memerlukan waktu yang cukup lama dalam proses penginterpretasiannya. Pemaknaan seni tidak lepas dari wujud simbolnya meskipun secara teoritik terpisah darinya. (Jakob Sumardjo: 43).

Teori mengenai kesenian yang merupakan media komunikasi juga berlaku pada kesenian di Lampung. Terdapat berbagai perspektif dalam mengkomunikasikan kesenian di Lampung, di antaranya adalah melalui sebuah kegiatan pesta kerakyatan yang disebut 'pesta sekura'. Terdapat banyak hal yang merepresentasikan kesenian pesta kerakyatan ini untuk dapat dikomunikasikan kepada orang lain. Kesenian sekura, seperti yang telah di jelaskan sebelumnya bahwa sekura adalah sebutan topeng untuk masyarakat Lampung.

Pada awal kemunculan topeng pada masyarakat Lampung digunakan untuk menyembunyikan identitas diri dari para penjajah. Ada beragam versi cerita yang menunjukkan tentang asal usul tradisi kesenian topeng sekura. Salah satunya menurut kepercayaan ajaran Hindu. Berdasarkan keyaninan dari umat Hindu, sekura berasal dari orang-orang yang tidak memiliki kepercayaan terhadap para dewa sehingga selalu melakukan hal- hal yang tidak terpuji. Lalu orang-orang tersebut di kutuk oleh dewa sehingga memiliki wajah yang buruk rupa seperti topeng. 
Versi cerita lainnya berdasarkan kepercayaan dari umat muslim. Kesenian topeng sekura menurut mereka adalah sebuah kesenian yang cukup berpengaruh terhadap perkembangan agama islam pada masa kerajaan Skala Brak yang merupakan kerajaan kuno di Lampung Barat. Konon katanya, kerajaan yang memiliki keyakinan dinamisme dan animisme ini sedikit demi sedikit dimasuki dan dipengaruhi oleh para penyebar agama islam ke dalam wilayah kerajaannya. Sehingga beberapa waktu berlalu agama islam berkembang dan menjadi komunitas yang relatif besar dalam kerajaan tersebut, terutama di daerah suku Tumi.

Dalam ajaran yang semakin meluas, secara tidak langsung mempengaruhi kehidupan di kerajaan Skala Brak. Terutama pada bagian dalam suku Tumi. Sebagian besar dari mereka mulai memeluk agama Islam, namun tidak sedikit juga yang menolaknya. Pada akhirnya suku tersebut terbelah menjadi dua dan perang saudara pun tidak bisa dhindari. Pada saat inilah mereka menggunakan topeng/sekura saat perang, dan berfungsi untuk melindungi dan menutup wajah satu sama lain dikarenakan sebagai penghilang dari rasa kasihan karena berperang melawan saudara satu suku.

Akan tetapi pada abad ke-19, pememakaian topeng beralih fungsi, tidak lagi digunakan untuk berperang, melainkan beralih fungsi sebagai sarana untuk memperkuat tali persaudaraan antar sesama. Semenjak itulah kemudian topeng/sekura banyak digunakan sebagai pemeriah perayaan Idul Fitri dan Idul Adha. Bahkan sampai saat ini perayaan dari kesenian topeng Sekura masih dilaksanakan di berbagai tempat berbeda.

Dari kedua versi yang berbeda inilah kemudian disimpulkan oleh para budayawan tentang asal usul dari sekura. Oleh karena itu dapat ditarik kesimpulan tentang alasan adanya dua jenis topeng/sekura, yaitu Sekura Kecah atau Sekura Bersih dan juga Sekura Kamak atau Sekura Kotor. 


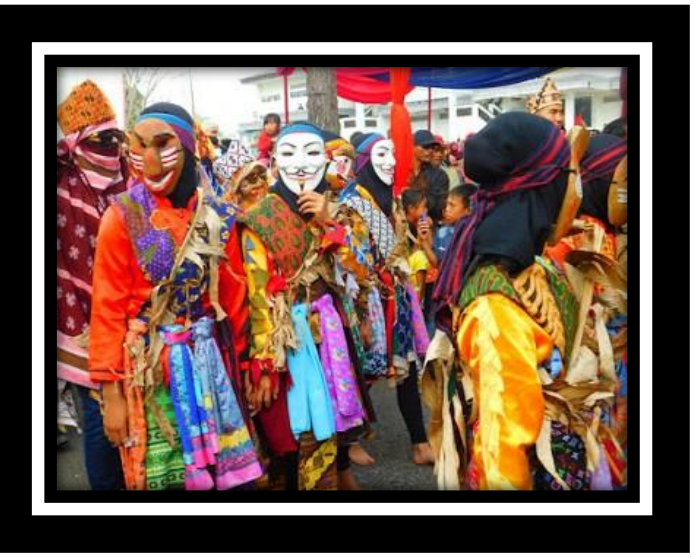

Gambar 1. Kostum Sekura Kecah atau Sekura Bersih Sumber: www.google.com, diakses 3 Januari 2016)

Kemunculan dari kesenian topeng/sekura ini tidak lepas dari penyebaran ajaran Islam di kerajaan Skala Brak kala itu. Sekura Kamak atau Sekura Kotor biasanya sering digunakan oleh para pendakwah sebagai sarana untuk sebuah penggambaran pribadi yang suka melawan dan pemberontak terhadap kepala pemerintahan yang menurut mereka zalim. Oleh karena hal inilah mereka menggunakan Sekura Kamak mendapatkan dukungan dari para kaum budak dan yang tertindas. Setelahnya itu para pendakwah mengganti topeng/Sekura Kamak dengan Sekura Kecah atau Sekura Bersih sebagai tanda bahwa masyarakat telah berada dalam kebersihan dan kesucian. Dengan cara inilah mereka mendapatkan perhatian dan kesan yang lebih menarik.

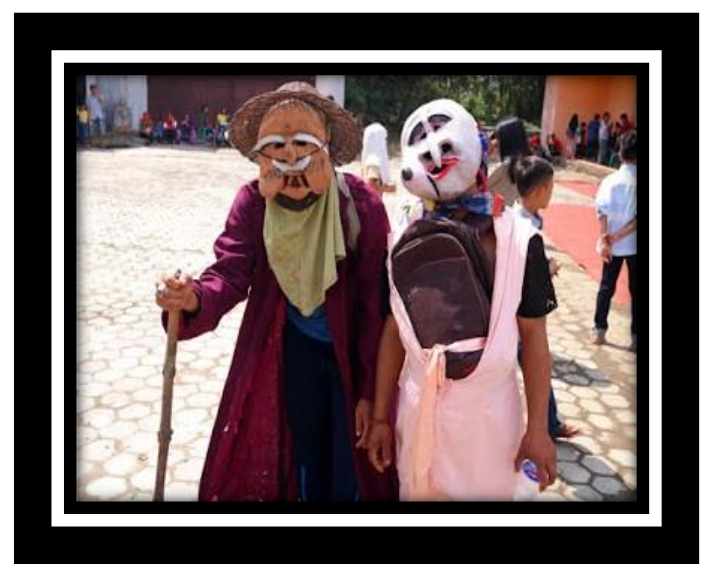

Gambar 2. Kostum Sekura kamak atau Sekura Kotor Sumber: www.google.com, diakses 3 Januari 2016) 
Kesenian topeng/sekura bukan sebuah tradisi yang tidak memiliki makna. Adapun makna sesungguhnya dari sekura adalah sebuah kekayaan budaya warisan nenek moyang yang sarat akan makna. Karena topeng ini juga merupakan sebuah bukti dari perjuangan yang konsisten dan juga bukti yang penting sebagai sarana mempersatukan anak bangsa yang sekaligus juga sebagai sarana kebebasan dan pengembangan ekspresi bagi seni topeng itu sendiri.

Tidak hanya dari segi fungsinya saja, sekura/tupping juga mengalami perubahan dari segi busana yang dikenakan. Pada awalnya sekura/tupping menggunakan perlengkapan serba kayu, mulai dari baju, celana, hingga topeng. Hingga pada awal kemerdekaan sekitar tahun 1945-1946 perlengkapan yang digunakan berubahan, tidak lagi dari bahan serba kayu melainkan dari kain (Hasil wawancara dengan salah satu tokoh adat Lampung, Novan Saputra).

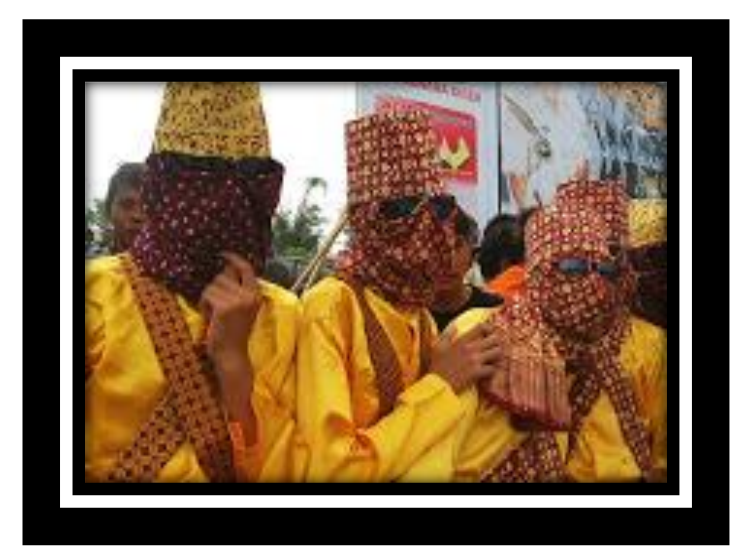

Gambar.3 Kostum sekura dengan menggunakan kain. Sumber: www.google.com, diakses 3 Januari 2016)

Kajian simbolik dalam teori heurmeneutik dengan pendekatan kontekstual digunakan pada paparan tulisan ini. Sebelumnya perlu diketahui bahwa pendekatan kontekstual yaitu telaah simbolik dan telaah struktural. Pada dasarnya kajian ini sama-sama menafsirkan karya seni kedalam teks yang dapat di baca. Namun perbedaannya terletak pada strukturalisme. Adapun penafsiran dilakukan setelah karya seni dianalisis secara struktural, sedangkan pada simbolik tidak melakukan itu.

Pada kesenian sekura, para pemainnya menggunakan topeng sebagai penutup identitas diri. Makna topeng pada kesenian ini tidak hanya menutupi wajah saja, namun juga keseluruhan tubuh si pemain, hingga identitasnya benar- 
benar tidak diketahui oleh para penikmatnya. Wujud kesenian ini seperti pada paparan sebelumnya.

Sementara teori heurmeneutik berarti menempatkan kesenian sebagai sebuah teks yang harus dibaca lalu ditafsirkan. Hermeneutik dalam konteks seni adalah menguraikan pengertian-pengertian atau makna dibalik teks (karya seni). Maka langkah penting dari hermeneutik adalah interprestasi (putra 402-403). Pada hal ini juga masuk pada ranah kontekstual, di dalamnya memuat makna dibalik suatu kesenian, dalam hal ini yakni kesenian sekura.

Diketahui sebelumnya bahwa kesenian sekura difungsikan sebagai penutup identitas diri yang tujuannya menghindari para penjajah pada masa lalu, sehingga menyimbolkan perlawanan bangsa Indonesia ketika itu. Meskipun ada versi lain yang menyatakan bahwa kesenian ini juga berfungsi untuk ritual dan bermakna magis atau dianggap sakral. Pada perkembangannya, kesenian sekura mengalami perubahan fungsi dan maknanya, sehingga turut berpengaruh pada wujud bentuknya. Yang mana pada awalnya menggunakan bahan kulit kayu, kemudian pada perkembangannya saat ini menggunakan bahan kain.

Fungsi dan makna tersebut selanjutnya diinterpretasikan. Kegiatan menginterprestasi berasal dari kata kerja Bahasa Inggis 'to interpret' yang berarti memaparkan secara rinci arti kata-kata asing, tulisan, mimpi dan sebagainya. Misalnya memaparkan penggambaran visual tentang suatu karya seni. Kata 'to interpret' berasal dari kata latin 'interpretari', yang artinya memaparkan atau menterjemahkan (Marianto, 45-46).

Interprestasi menurut Paul Ricoer adalah penyingkapan suatu maksud yang lebih dalam, yakni penjembatanan distansi dan perbedaan-perbedaan budaya. Interprestasi menghadapkan pembaca pada teks yang telah menjadi suatu yang asing dan memaknainya menurut pemahaman orang tersebut.

Sebuah teks bersifar otonom, karena secara alamiah selalu terjadi distansi. Proses distansi ini akan membuat teks tercerabut dari konteks aslinya bahkan maknanya dapat bertolak belakang dari maksud pembuatnya (Triatmoko dalam Marianto, 46-47).

Berdasarkan penjelasan yang telah dipaparkan tersebut, sekura/tupping memiliki dua fungsi yang berbeda, yakni sebagai penutup identitas diri dan sarana 
hiburan masyarakat setempat. Meskipun kedua fungsi tersebut saat ini tidak lagi digunakan seluruhnya.

Fungsi yang saat ini lebih sering digunakan adalah sekura/tupping sebagai sarana hiburan pada pesta kesenian rakyat. Makna yang terkandung dalam sekura/tupping yang hadir pada pesta kesenian rakyat ini semata-mata hanya sebagai sarana hiburan atau tontonan.

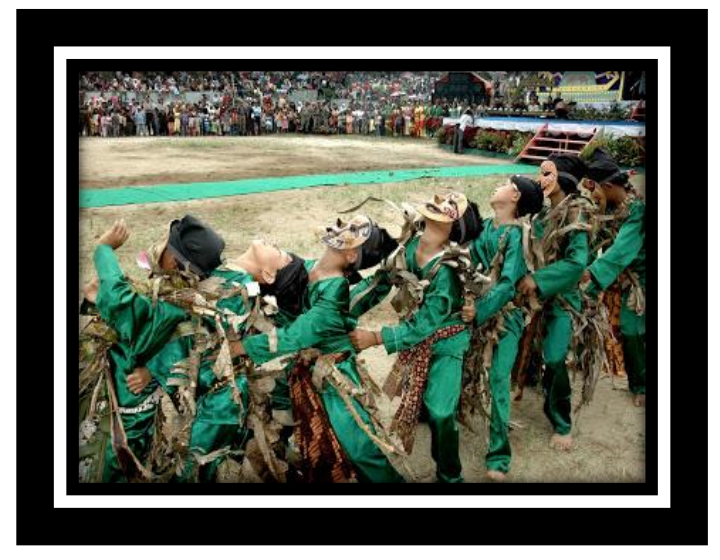

Gambar 4. Kesenian sekura pada pesta rakyat. Sumber: www.google.com, diakses 3 Januari 2016)

Berdasarkan penjelasan yang ada, makna-makna yang telah disampaikan terdapat beberapa nilai diantaranya nilai sosial, politik, budaya, religi, etika, dan estetika. Pada dasarnya sekura/tupping bukan hanya sekedar penutup wajah atau bagian dari pesta kesenian rakyat saja, melainkan terdapat sejarah yang begitu besar didalamnya. Sejarah tersebut dapat dijadikan tatanan dan tuntunan untuk aktivitas kehidupan saat ini.

Dalam wawancara dengan beberapa penonton pada saat pesta kesenian rakyat sekura berlangsung, nilai-nilai yang terdapat pada pesta kesenian rakyat ini tersampaikan dengan jelas, sebab hampir sebagian besar penonton adalah orangorang yang mengetahui dan paham mengenai sekura/tupping ini.

Sekura/tupping sangat dekat keberadaannya dengan masyarakat Lampung, tidak hanya digunakan pada saat pesta kesenian rakyat saja sekura/tupping telah banyak mengalami perkembangan. Saat ini sekura/tupping telah dijadikan sebuah pertunjukan berupa pertunjukan tari dan teater, bahkan saat ini sekura/tupping menjadi salah satu kerajinan yang dapat menciptakan lapangan pekerjaan dan membantu perekonomian masyarakat Lampung. Banyak media yang kini 
TERAMPIL

Jurnal Pendidikan dan Pembelajaran Dasar

Volume 5 Nomor 1 Juni 2018

p-ISSN 2355-1925

e-ISSN 2580-8915

digunakan untuk membuat jenis topeng ini, seperti kulit kayu, kayu, viber, kertas keras dan sebagainya. Pembuatan sekura/tupping pada masa kini disesuaikan dengan kebutuhan pemakaian sekura/tupping itu sendiri.

Selain beberapa perkembangan yang telah disebutkan, perkembangan lainnya berupa masuknya kesenian sekura pada ranah pendidikan. Saat ini kesenian sekura cenderung banyak dijadikan sebagai meteri pembelajaran, khususnya bagi siswa Sekolah Dasar (SD). Dari berbagai unsur yang terdapat di dalam pesta kesenian sekura, dunia pendidikan dapat memberikan ilmu pengetahuan kepada siswa SD mengenai sejarah, pembuatan topeng sekura, dan perkembangan sekura sebagai pertunjukan tari.

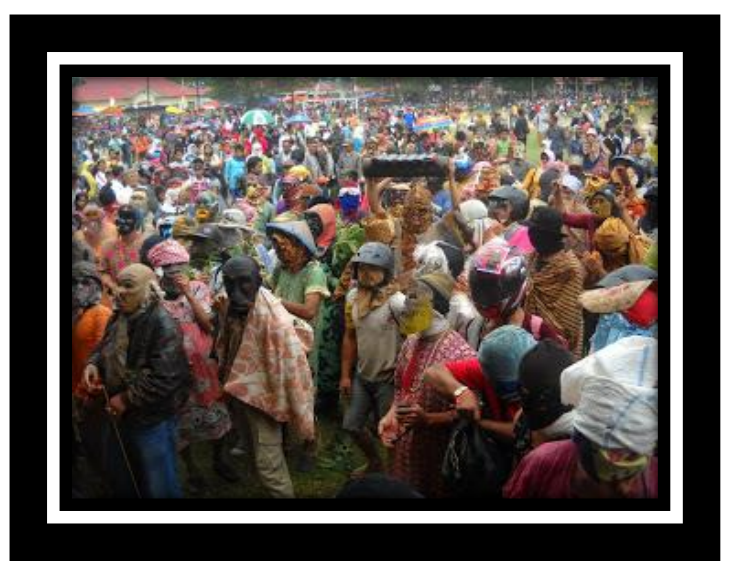

Gambar 5. Kemeriahan sekura pada pesta rakyat. Sumber: www.google.com, diakses 3 Januari 2016)

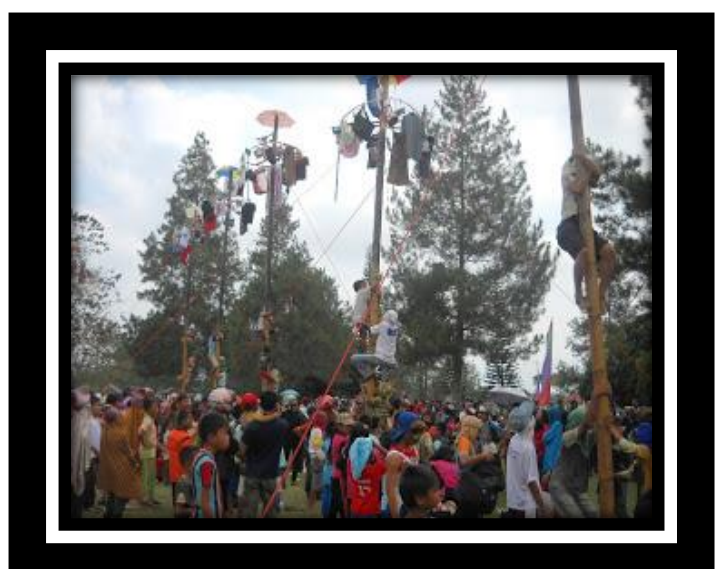

Gambar 6. Kemeriahan sekura pada pesta rakyat.

Sumber: www.google.com, diakses 3 Januari 2016)

Pendekatan filosofis psikologi pendidikan sebagai upaya pencapaian tujuan pembelajaran kesenian sekura di SD tunas mekar Indonesia, Bandar Lampung 
Dapat dilihat pula dari gambar 6, bahwa pesta kesenian rakyat sekura identik dengan adanya pohon pinang yang telah dikuli lalu di beri oli pada badian batang dan pada bagian ujung batang di beri berbagai macam barang yang nantinya akan dijadikan ajang 'panjat pohon pinang'. Berbagai macam barang yang nantinya di dapatkan oleh para pelaku sekura akan dibagi-bagikan kepada masyarakat sekitar yang menghadiri pesta kesenian rakyat tersebut.

Pesta kesenian rakyat yang berupa 'panjat pohon pinang' ini dilakukan setiap hari raya (Idul Fitri dan Idul Adha), juga menjadi agenda tahunan yang kini masuk kedalam daftar tujuan pariwisatan tahun bagi wisatawan asing maupun lokal. Hal ini dapat dikaji dari segi pelaku seni publik atau orang-orang yang terlibat langsung di dalamnya.

Penulis sebagai participan observer, mengamati secara langsung pertunjukkan kesenian sekura di Lampung Barat, tepatnya di Desa Canggu, pada perayaan Hari Raya Idul Fitri tahun 2016. Pada saat itu sekura dimainkan oleh para pemuda kampung setempat. Pada pelaksanaannya dilakukan secara bergiliran dari para pemuda di satu kampung ke kampung lainnya. Selanjutnya dilihat bentuknya, para pemain sekura menggunakan kostum sekura yang tidak lazim digunakan bagi kaum lelaki, seperti daster, pakaian wanita, dsb.

Pertunjukkan tersebut dinikmati oleh seluruh masyarakat setempat sebagai publik kritis. Hal ini dikarenakan seluruh masyarakat setempat mengetahui dengan sangat baik perihal sejarah dan perkembangan sekura. Selain itu dihadiri pula oleh wisatawan lokal dan wisatawan mancanegara sebagai publik partisipan. Kemudian dilengkapi pula dengan publik snobis, seperti kepala dinas setempat, para pejabat daerah setempat, dan para pengusaha setempat. Mereka adalah orangorang yang telah menyumbang dana agar acara tersebut dapat terlaksana.

Adapun sejarah tentang asal usul kesenian sekura lebih lanjut dibahas melalui mata pelajaran sejarah. Kemudian bentuk kesenian sekura yang terfokus pada topeng dibahas pada materi seni rupa. Selanjutnya gerak tari dalam kesenian sekura pun dibahas dalam materi seni tari.

Materi yang disampaikan cenderung terfokus pada pewarisan budaya Lampung. Adapun transformasi perkembangan secara ilmu pengetahuan 
disampaikan di dalam kegiatan pembelajaran kelas. Dilengkapi pula kegiatan pembelajaran yang mengacu pada keterampilan siswa.

Hal tersebut tampak pada praktek siswa mengumpulkan artikel tentang asal usul kesenian sekura dalam mata pelajaran sejarah. Selain itu tampak pula hasil praktik pembuatan topeng sekura dalam materi praktik seni rupa, dan hasil produk tarian dalam kegiatan ekstrakurikuler seni tari. Keseluruhan pembelajaran didampingi oleh guru sebagai tutor sekaligus pendamping siswa.

Karakter yang diharapkan dalam tujuan pembelajaran pun perlahan tampak melalui proses pembelajaran tersebut. Dengan demikian diharapkan kelak para peserta didik dapat menjadi anggota masyarakat yang tak hanya berguna dalam hal pengetahuan dan keterampilan terkait budaya lokal, namun juga memiliki karakter yang dapat diandalkan dalam hidup bermasyarakat.

\section{E. KESIMPULAN}

Pada penelitian yang dilakukan di kelas 4 SD Tunas Mekar Indonesia, Bandar Lampung diupayakan pencapaian karakter dalam tujuan pembelajaran melalui substansi materi kesenian sekura. Upaya tersebut dilakukan melalui pendekatan filosofis psikologi pendidikan.

Adapun hasil penelitian yang mengacu pada pendekatan filosofis psikologi pendidikan dalam aliran essensialisme mengacu pada fase sekolah (umur 6-12 tahun). Menurut Erikson hasil perkembangan ego pada fase ini adalah industri vs inferior. Kekutan dasarnya adalah metode dan kompetisi. Selama tahap ini, sering disebut 'latency', manusia mampu belajar, menciptakan, dan menyelesaikan berbagai keterampilan baru serta pengetahuan, dengan demikian mengembangkan semangat industri atau mencipta (Sudarman Danim dan H. Khairil, 2010: 72-73).

Pada penelitian ini tampak para siswa yang berusia antara 9-10 tahun saling berkompetisi dalam menangkap ilmu pengetahuan dan keterampilan pada pembelajaran kesenian sekura. Pada proses perolehan ilmu tersebut secara tak langsung para siswa belajar untuk mandiri, bertanggung jawab, dan bekerja keras demi mendapatkan hasil yang maksimal.

Selain itu juga perlahan terbentuk penanaman sikap saling menghargai, menghormati, dan peduli baik terhadap sesama teman, lingkungan, maupun hasil 
karya yang dihasilkan diri sendiri dan orang lain. Pada fase ini para siswa belajar bermasyarakat secara lebih luas tanpa didampingi kedua orang tua, meskipun kehadiran kedua orang tua masih dianggap penting.

\section{F. DAFTAR PUSTAKA}

Sudarwan Danim dan H. Khairil. 2010. Psikologi Pendidikan. Bandung: ALFABETA.

Depdikbud. 1985. Adat Istiadat Daerah Lampung. Departemen Pendidikan dan Kebudayaan.

Jess Feist \& Gregory J Feist. 2010. Teori Kepribadian. Jakarta: Salemba Humanika.

Guide book. 2007. Jakarta: taman mini Indonesia indah

Y. Sumandiyo Hadi. 2004. Aspek-aspek Dasar Koreografi Kelompok. Yogyakarta: ELKAPHI.

M. A. Hamdani. 2011. Strategi Belajar Mengajar. Bandung: CV. Pustaka Setia.

Alma M Hawkins. 2003. Bergerak Menurut Kata Hati, di Indonesia oleh I wayan Dibia. Jakarta: Ford Foundation dan MSPI.

“Informasi pariwisata kabupaten Lampung Barat". 2007. Dinas pariwisata kebudayaan promasi dan investasi.

Sumardjo Jakob. 2006. Estetika Paradoks. Bandung: SUNAN AMBU PRESS, STSI Bandung.

Koentjaraningrat. 2015. Pengantar Ilmu Antropologi. Jakarta: PT. RINEKA CIPTA.

Lameri. 1989. Elemen-elemen Dasar komposisi Tari. Terjemahan Soedarsono Yogyakarta Lagaligo. ISI Yogyakarta.

Moch Munir. "Pedoman program kreatifda mahasiswa". 2009. Departemen pendidika mn nasional. Jakarta

Murgianto, Sal dkk. 1989. Pengetahuan elementer Tari dan Beberapa Masalah Tari. Jakarta: Direktorat Kesenian.

Suharsimi Arikunto. 2006. prosedur penelitian suatu pendekatan praktik. Jakarta: PT RINEKA CIPTA. 
R. M soedarsono. 1978. Pengantar Pengetahuan dan Komposisi Tari. Yogyakarta: ASTI.

Jacqueline Smith. 1985. Komposisi Tari: Sebuah Petunjuk Praktis Bagi Guru. Terjemahan Ben Suharto Yogyakarta: IKALASTI.

Margery J Tuner. 2007. Pendekatan Koreografi Nonliteral. Terjemahan Y. Sumandiyo Hadi Yogyakarta.

http://budaya.ijomuda.com/makna-dari-kesenian-topeng-sekura-lampung/

Novan Adi Putra, usia 30 tahun, sebagai seniman Lampung, Alamt Bandar Lampung. 